\title{
ASSOCIATION BETWEEN WORK UNIT PREVALENCE OF POOR WORIK ABILITY AND SOCIAL CAPITAL - A CROSS-SECTIONAL ANALYSIS OF 63 PUBLIC SECTOR WORIK UNITS
}

\author{
Kiss P.1,2, De Meester M.1,2, Kristensen T. S.3, Clays E.2, Braeckman L.2 \\ ISecurex Occupational Health Service, Belgium \\ 2Department of Public Health and Primary Care, Ghent University, Belgium \\ 3Task-Consult, Gilleleje, Denmark
}

Purpose. The aim of the study was to explore the association between work unit prevalence of poor work ability and social capital within a public sector population.

Methods. 836 subjects belonging to 63 well defined work units (mean response rate per work unit: $84.8 \%$ ) in seven public sector organizations took part in a cross-sectional questionnaire study. Associations between poor work ability (Work Ability Index $<37$ ), physical workload, need for recovery and social capital were explored on work unit level using bivariate correlations and multiple linear regression analysis.

Results. Significant correlations were found between work ability, work unit social capital (r: -0.311) and high need for recovery (r: 0.501). In the multivariate analysis need for recovery (standardized $\beta 0.521$ ) and workplace social capital (standardized $\beta-0.321$ ) were significantly associated with work ability at work unit level.

Conclusions. The findings of our study are suggestive for an important role of need for recovery and workplace social capital in maintaining work ability in the public sector. Factors that decrease need for recovery and increase workplace social capital need to be considered for improving work ability.

Key words: work ability, need for recovery, workplace social capital, physical workload, public sector

\section{Introduction}

Due to the economic and political tendency to raise the retirement age, people will have to work longer. Organizations will have to deal with the challenges of an ageing workforce, and by extension with the challenges of maintaining employability in a continuously changing working environment. Within the context of a longer working life and sustainable employability, the concept of promoting and maintaining work ability takes a predominant place.

Work ability is the balance between the demands at work and the individual resources of the employees. When work and individual resources fit well together, work ability is good [1, 2]. Long term follow-up studies have indicated that work ability is predictive for future work disability: moderate and poor work ability have been shown to be highly predictive for early retirement and disability pension [3-7].

Recent research has suggested that workplace social capital could be an important factor for the psychosocial work environment [8]. Workplace social capital can be described as the collaborative capabili- ties of an organization, based on trust and justice [9] and applies to every group of employees that work together, ranging from the entire organization to the work unit or team. On work unit level the concept of workplace social capital can be operationalized as a characteristic of the work unit consisting of three dimensions: collaboration, trust, and justice [10]. Recent research showed workplace social capital to be an important factor related to health and mental disorders [11-17].

Physical workload has been demonstrated to be an important factor in the development of musculoskeletal complaints [18]; the latter being the most important cause for early exit for health reasons. As it was shown that physical workload had an important influence on work ability and early retirement [19-23], this factor should be taken into account when studying relationships with work ability.

Need for recovery is considered to be a sensitive indicator of reduced well-being [24]. The concept of need for recovery is concordant with the cognitive activation theory of stress. In this theory stress response is defined as an alarm in a homeostatic 
system, producing neurophysiological activation. The activation can be reduced by coping mechanisms, triggered by the same alarm. If the coping mechanisms are inadequate to reduce the activation level, a certain aroused activation level remains. If sustained this may lead to adverse health effects [25]. In an occupational setting, fatigue experienced during or after a day's work can lead to long term adverse health effects, when there is insufficient time to recover from this fatigue in between two work periods [26] Increased need for recovery was shown to be a predictor for psychosomatic complaints, emotional exhaustion and duration of future sickness absence [27-29].

Need for recovery is influenced by a number of psychosocial factors (both occupational and nonoccupational) [30] and can be considered as an effect measure of psychosocial factors. Recently, a significant negative correlation was found between need for recovery and the single-item version of the Work Ability Index [31]. Taking the need for recovery into account as a confounding variable, enables to control for the effect of psychosocial factors on work ability.

In an earlier study a highly significant correlation was found between workplace social capital and prevalence of poor work ability [10]. The small amount of work units $(n=11)$ in this study did not allow to perform multivariate analyses. Other factors that could influence work ability are physical workload, need for recovery and age. Therefore, the aim of the current study was to explore the association between work unit prevalence of poor work ability and social capital within a larger amount of work units in a public sector population, controlling for physical workload, need for recovery and age.

\section{Methods}

The study has been approved by the Ethics Committee Progecov-Securex (Commissie voor Medische Ethiek OG 211, Ghent, Belgium).

\section{Study design and study population}

This was a cross-sectional questionnaire study. All subjects were asked to fill out a standardized selfcompleted questionnaire.

The target population consisted of 986 subjects, working in 63 work units of seven public sector organizations, and included administrative workers, library workers, professional fire fighters, police officers, teachers, technical personnel, cleaning personnel, social service, child care, cleaning at home, nursing personnel, nursing at home, kitchen personnel and harbour personnel. Eventually, 836 subjects took part in the study (overall response rate $84.8 \%$ ). The mean number of workers per work unit was 13.2, with a range of 5-41 workers. Mean response rate per work unit was $83.8 \%$ (range $57.7-100$ ).

\section{Work ability}

Work ability was assessed by the Work Ability Index (WAI) questionnaire. The WAI questionnaire has proven to be an instrument with good internal and predictive validity [32] and test-retest reliability [33], applicable for the assessment of work ability in occupational health research and daily occupational health practice. The WAI covers seven items, each of which is evaluated with the use of one or more questions: current work ability compared with the lifetime best, work ability in relation to the demands of the job, number of current diseases diagnosed by a physician, estimated work impairment due to diseases, sick leave during the past 12 months, own prognosis of work ability two years from now and mental resources (referring to the worker's life in general, both at work and during leisure time). The WAI is calculated by adding up the estimated points for each item, resulting in a WAI score ranging from 7 to 49 (the higher the score, the better the work ability). Work ability is considered to be «poor» if the WAI score ranges from 7 to 27 , «moderate» in the range of 28 to 36 , «good» in the range of 37 to 43 and «excellent» if the WAI score ranges from 44 to 49 [34].

In the current study work ability was assessed by the short version of the WAI as used in the Nurses' Early Exit Study (NEXT study) [35]. Scoring for the short WAI is analogous to the scoring for the long version of the WAI [34].

Due to the very low prevalence of workers with a «poor» WAI score (27 or less) (2.2\%), it was decided to dichotomize the WAI score into a group comprising the workers with «poor» and «moderate» WAI score $(<37)$ and a group of workers with «good» and «excellent» WAI score $(\geq 37)$. WAI score lower than 37 was defined as poor work ability.

\section{Physical workload}

Physical workload was assessed by a four item physical workload scale, comprising sustained physical efforts, repetitive work, lifting heavy weights and 
working in awkward positions. For each separate item, a frequency-based answer could be given (four possibilities: never, sometimes, often and always), resulting in a score from 0 to 3 per item. The physical workload scale was computed by summing up the scores of the four constituent items and transformed into a $0-10$ scale. The highest score was concordant with the highest physical workload. Cronbach's $\alpha$ of the scale was 0.82 , with inter-item correlations ranging from 0.48 to 0.61 . The reliability figures were similar to those reported in earlier studies $[10,36]$.

\section{Workplace social capital}

Workplace social capital was assessed with a scale comprising six questions, derived from the subscales «vertical trust», «justice» and «social community at work» of the COPSOQ II [8]. Recent research corroborated the social capital scales included in COPSOQ II to be valid measures [37]. Each subscale was asked for in two questions offering five response options. The dimension was transformed into a $0-10$ scale; the higher the score, the higher workplace social capital. Cronbach's $\alpha$ of the scale was 0.74 (inter-item correlations $0.11-0.66$ ), which was comparable to reliability reported earlier [10].

\section{Need for recovery}

Need for recovery after work was assessed by «The Need for Recovery Scale», which has proven to be a reliable instrument [38, 39]. «The Need for Recovery Scale» questionnaire comprises 11 dichotomous (yes/no) items [40]. The need for recovery scale was computed by summing up the scores of the 11 constituent items, resulting in a score ranging from 0 to 11, which was transformed to a 0 to 100 scale [29, 39]. Higher scores indicate a higher degree of need for recovery after work. Cronbach's $\alpha$ of the scale was 0.85 (inter-item correlations $0.17-0.64$ ), which was comparable to reliabilities reported earlier [26, 28, 30, $36,38,41]$. Receiver operating characteristic analyses for long term health effects (psychic and psychosomatic complaints) showed that a need for recovery score higher than 45 is equivalent to a high need for recovery [42].

\section{Considered confounding variable}

Age was asked for as a continuous variable. The subjects were divided into two age groups: older workers ( 45 years or older) and younger workers (younger than 45 years), according to the WHO definition of older workers [43]. The proportion of older workers was taken into account as confounding variable.

\section{Statistical analyses}

All data analyses were performed using IBM SPSS Statistics, version 22 [44].

Variables were treated as work unit characteristics: work unit prevalence of poor work ability, mean work unit social capital value (mean of the individual values of all the workers working in that work unit), work unit prevalence of high need for recovery, mean work unit physical workload (mean of the individual physical workload scale values of all the workers working in that work unit) and work unit proportion of older workers.

The considered variables were described by mean, distribution range and standard deviation.

To evaluate the correlation between all considered variables Pearson's correlation coefficients were calculated.

Multiple linear regression analysis was carried out using work unit prevalence of poor work ability as dependent variable. Following independent variables were entered in the regression model: work unit proportion of older workers; mean work unit physical workload; mean work unit social capital value and work unit prevalence of high need for recovery. Regression coefficients $(\beta)$, standardized regression coefficients and $p$ values were computed.

\section{Results}

Table 1 summarizes the descriptives of the considered variables on work unit level.

The correlation matrix of all the considered variables is shown in Table 2. The highest and most significant correlation was found between prevalence of poor work ability and prevalence of high need for recovery. A reversed significant correlation was found between prevalence of poor work ability and work unit social capital. There was also a significant positive correlation between work unit physical work load and prevalence of high need for recovery.

The results of the multiple linear regression analysis for the 63 considered work units are given in Table 3 . Both workplace social capital and need for recovery were significantly associated with work ability on work unit level. An increasing prevalence of high need for recovery was strongly associated with an increasing 
Descriptives of the considered work unit variables: work unit prevalence (\%) of poor work ability; mean work unit social capital (mean WUSC); work unit prevalence (\%) of high need for recovery; mean work unit physical workload; work unit proportion of workers $\geq 45 \mathrm{yr}$ ( $\%$ older workers)

\begin{tabular}{|l|c|c|c|c|}
\hline & n & mean & range & SD \\
\hline \% poor work ability & 63 & 12.9 & $0.0-57.1$ & 12.8 \\
\hline mean WUSC scale (0-10) & 63 & 6.8 & $4.1-8.2$ & 0.9 \\
\hline \% high need for recovery & 63 & 25.5 & $0.0-80.0$ & 17.6 \\
\hline mean physical workload scale (0-10) & 63 & 3.5 & $1.0-7.4$ & 1.7 \\
\hline \% older workers & 63 & 45.2 & $0.0-93.3$ & 23.0 \\
\hline
\end{tabular}

Matrix of Pearson's correlation coefficients for prevalence of poor work ability (\% poor WA), work unit social capital (WU SC), prevalence of high need for recovery (\% HNFR), work unit physical work load (WU PWL) and proportion of older workers (\% OW) for the 63 work units

\begin{tabular}{|l|c|c|c|c|c|}
\hline & \% poor WA & WU SC & \% NFR & WU PWL & \% OW \\
\hline \% poor WA & 1 & & & & \\
\hline WU SC & $-0.311^{*}$ & 1 & & & \\
\hline$\%$ HNFR & $0.501^{* *}$ & 0.056 & 1 & & 1 \\
\hline WU PWL & 0.219 & -0.249 & $0.318^{*}$ & 0.123 & 1 \\
\hline$\%$ OW & 0.246 & -0.229 & 0.092 & & \\
\hline
\end{tabular}

${ }^{*} p<0.05,{ }^{* *} p<0.01$

prevalence of poor work ability. Mean workplace social capital was inversely related to work unit prevalence of poor work ability: an increasing mean work unit social capital was associated with a decreasing prevalence of poor work ability.

\section{Discussion}

Both univariate and multivariate analyses showed similar results: a reversed significant relationship between prevalence of poor work ability and work unit social capital, and a strong positive relationship between prevalence of poor work ability and prevalence of high need for recovery.

The results of the multiple regression analysis in the current study confirmed earlier findings of the univariate analysis in public nursing homes between social capital and work ability [10], and allows to extrapolate the earlier findings to a wider array of jobs in the public sector: a significant negative relationship exists between work unit social capital and prevalence of poor work ability.

The percentage of high need for recovery was the most significantly associated factor with prevalence of poor work ability. This finding is completely compatible with the findings of the two earlier studies, where a significant relationship was found between need for recovery and work ability in construction workers [45] and meat processing workers [46].

Mean work unit physical workload was not significantly associated with prevalence of poor work ability, both in univariate and multivariate analysis.

Table 3

Multiple linear regression model $(n=63)$ with regression coefficients $(\beta)$ and $p$-values for the association of mean work unit social capital, work unit prevalence of high need for recovery, mean work unit physical workload, and work unit proportion of older workers with work unit prevalence of poor work ability

\begin{tabular}{|l|c|c|c|}
\hline & $\boldsymbol{\beta}$ & Standardized $\boldsymbol{\beta}$ & $\mathbf{p}$ \\
\hline mean WUSC (0-10) & -4.655 & -0.321 & 0.005 \\
\hline \% high need for recovery & 0.377 & 0.521 & $<0.001$ \\
\hline mean physical workload (0-10) & -0.321 & -0.043 & 0.709 \\
\hline \% older workers & 0.072 & 0.130 & 0.228 \\
\hline \hline
\end{tabular}


However, a significant correlation was found with prevalence of high need for recovery. This finding is concordant with results of earlier studies [27, 30, 47], was a significant relationship was found between physical work load and need for recovery on individual level.

This was a cross-sectional study, making it difficult to point out causal relationships. Longitudinal studies

\section{References}

1. Ilmarinen J. (2009), «Work ability - a comprehensive concept for occupational health research and prevention", Scand $J$ Work Environ Health, 35, 1-5. https://doi. org/10.5271/sjweh.1304.

2. Ilmarinen J. (2012), Promoting Active Ageing in the Workplace [European Agency for Safety and Health at Work (EU-OSHA) website]. June 26, 2012. Available at: https: / / osha.europa.eu / sites / default/files / publications/documents/en/publications/articles/ promoting-active-ageing-in-the-workplace/activeageing-in-the-workplace_en.pdf. (Accessed November 16, 2016).

3. Sell L., Bultmann U., Rugulies R. et al. (2009), "Predicting long-term sickness absence and early retirement pension from self-reported work ability", Int Arch Occup Environ Health, 82, 113-118. https://doi. org/10.1007/s00420-009-0417-6.

4. Alavinia S. M., de Boer A. G. E. M., van Duivenbooden J. C. et al. (2009), "Determinants of work ability and its predictive value for disability", Occup Med, 59, 32-37. https://doi.org/10.1093/occmed/kqn148.

5. Roelen C. A., Heymans M. W., Twisk J. W. et al. (2014), "Work Ability Index as tool to identify workers at risk of premature work exit", J. Occup Rehabil, 24, 747754. https://doi.org/10.1007/s 10926-014-9505-x.

6. von Bonsdorff M. E., Rantanen T., Törmäkangas T. et al. (2016), "Midlife work ability and mobility limitation in old age among non-disability and disability retirees - a prospective study", BMC Public Health, 16, 154. https:// doi.org/10.1186/s12889-016-2846-y.

7. Jääskeläinen A., Kausto J., Seitsamo J. et al. (2016), "Work ability index and perceived work ability as predictors of disability pension: a prospective study among Finnish municipal employees", Scand J. Work Environ Health, 42, 490-499. https://doi.org/10.5271/ sjweh.3598.

8. Pejtersen J. H., Kristensen T. S., Borg V. and Bjorner J.B. (2010), "The second version of the Copenhagen Psychosocial Questionnaire", Scand J. Public Health, 38 (Suppl 3), 8-24. https://doi. org/10.1177/ 1403494809349858.

9. Kristensen T. S. (2010), "A questionnaire is more than a questionnaire", Scand J Public Health, 38(Suppl 3), 149155. https://doi.org/10.1177/1403494809354437. should be carried out to clarify the causal relationships.

In conclusion, the findings of our study are suggestive for an important role of need for recovery and workplace social capital in maintaining work ability. Factors that decrease need for recovery and increase workplace social capital need to be considered for improving work ability in a public sector population.

10. Kiss P., De Meester M., Kristensen T. S. and Braeckman L. (2014), "Relationships of organizational social capital with the presence of "gossip and slander," "quarrels and conflicts," sick leave, and poor work ability in nursing homes", Int Arch Occup Environ Health, 87, 929-936. https://doi.org/10.1007/s00420-014-0937-6.

11. Jung J., Ernstmann N., Nitzsche A. et al. (2012), "Exploring the association between social capital and depressive symptoms. Results of a survey in German information and communication technology companies", J. Occup Environ Med, 54, 23-30. https://doi.org/ 10.1097/JOM.0b013e318237a1b6.

12. De Clercq B., Clays E., Janssens H. et al. (2013), "Reciprocity and depressive symptoms in Belgian workers. A cross-sectional multilevel analysis", J. Occup Environ Med, 55, 824-831. https://doi.org/10.1097/ JOM.0b013e31828dc8cd.

13. Kouvonen A., Oksanen T., Vahtera J. et al. (2008), "Low workplace social capital as a predictor of depression - The Finnish public sector study", Am J. Epidemiol, 167, 1143-1 151. https://doi.org/10.1093/aje/kwn067.

14. Oksanen T., Kouvonen A., Vahtera J. et al. (2010), "Prospective study of workplace social capital and depression: are vertical and horizontal components equally important?», J. Epidemiol Community Health, 64, 684-689. https://doi.org/10.1136/jech.2008.086074.

15. Kim S.-S., Chung Y., Perry M. J. et al. (2012), "Association between interpersonal trust, reciprocity, and depression in South Korea: a prospective analysis", PLoS One, 7 (1), e30602. Available from: PLOS ONE. (Accessed August 5, 2012). https://doi.org/10.1371/ journal.pone.0030602.

16. Driller E., Ommen O., Kowalski C. et al. (2011), "The relationship between social capital in hospitals and emotional exhaustion in clinicians: a study in four German hospitals", Int J. Soc Psychiatry, 57, 604-609. https://doi.org/10.1177/0020764010376609.

17. Kowalski C., Ommen O., Driller E., et al. (2010), "Burnout in nurses - the relationship between social capital in hospitals and emotional exhaustion", J. Clin Nurs, 19, 1654-1663. https://doi.org/10.1111/j.13652702.2009.02989.x.

18. de Zwart B. C. H., Broersen J. P. J., Frings-Dresen M. H. W. and van Dijk F. J. H. (1997), "Repeated survey on changes in musculoskeletal complaints relative to age 
and work demands", Occup Environ Med, 54, 793-799. https://doi.org/10.1136/oem.54.11.793.

19. Lund T., Iversen L. and Poulsen K. (2001), "Work environment factors, health, lifestyle and marital status as predictors of job change and early retirement in physically heavy occupations", Am J. Ind Med, 40, 161169. https://doi.org/10.1002/ajim. 1084.

20. Geuskens G. A., Oude Hengel K. M., Koppes L. L. J. and Ybema J. F. (2012), «Predictors of the willingness and the ability to continue working until the age of 65 years", J. Occup Environ Med, 54, 572-578. https://doi. org/10.1097/JOM.0b013e318248057a.

21. Oude Hengel K. M., Blatter B. M., Geuskens G. A. et al. (2012), "Factors associated with the ability and willingness to continue working until the age of 65 in construction workers", Int Arch Occup Environ Health, 85, 783-790. https://doi.org/10.1007/s00420-011-0719-3.

22. van den Berg T. I. J., Elders L. A. M., de Zwart B. C. H. and Burdorf A. (2009), "The effects of work-related and individual factors on the Work Ability Index: a systematic review", Occup Environ Med, 66, 211-220. https://doi. org/10.1136/oem.2008.039883.

23. van den Berg T., Elders L. and Burdorf A. (2010), "Influence of health and work on early retirement", $J$. Occup Environ Med, 52, 576-583. https://doi. org/10.1097/JOM.0b013e3181de8133.

24. Sonnentag S. and Zijlstra F. R. H. (2006), "Job characteristics and off-job activities as predictors of need for recovery, well-being, and fatigue", J. Appl Psychol, 91, 330-350. https://doi.org/10.1037/0021-9010.91.2.330

25. Ursin H. and Eriksen H. R. (2004), "The cognitive activation theory of stress", Psychoneuroendocrinology, 29, 567-592. https://doi.org/10.1016/S03064530(03)00091-X.

26. Sluiter J. K., Van der Beek A. J. and Frings-Dresen M. H. W. (1999), "The influence of work characteristics on the need for recovery and experienced health: a study on coach drivers», Ergonomics, 42, 573-583. https://doi. org/10.1080/001401399185487.

27. Sluiter J. K., de Croon E. M., Meijman T. F. and Frings-Dresen M. H. W. (2003), "Need for recovery from work related fatigue and its role in the development and prediction of subjective health complaints", Occup Environ Med, 60 (Suppl 1), i62-i70. https://doi.org/ 10.1136/oem.60.suppl_1.i62.

28. de Croon E. M., Sluiter J. K. and Frings-Dresen M. H. W. (2003), "Need for recovery after work predicts sickness absence. A 2-years prospective cohort study in truck drivers", J. Psychosom Res, 55, 331-339. https:// doi.org/10.1016/S0022-3999(02)00630-X.

29. de Croon E. M., Sluiter J. K., Blonk R. W. B. et al. (2004), «Stressful work, psychological job strain, and turnover: a 2-year prospective cohort study of truck drivers", J. Appl Psychol, 89, 442-454. https://doi. org/10.1037/0021-9010.89.3.442
30. Kiss P., De Meester M. and Braeckman L. (2008), "Differences between younger and older workers in the need for recovery after work", Int Arch Occup Environ Health, 81, 311-320. https://doi.org/10.1007/s00420007-0215-y.

31. Wentz K., Gyllensten K., Archer T. (2017), "Recording recovery opportunities at work and functional fatigue after work: two instruments adapted to the Swedish context", COJ Nurse Healthcare, 1 (2). https:// doi.org/10.31031/COJNH.2017.01.000507

32. Tuomi K., Ilmarinen J., Seitsamo J. et al. (1997), "Summary of the Finnish research project (1981-1992) to promote the health and work ability of aging workers. Eleven-year follow-up of aging workers", Scand J. Work Environ Health, 23 (Suppl 1), 66-71.

33. de Zwart B. C. H., Frings-Dresen M. H. W. and van Duivenbooden J. C. (2002), "Test-retest reliability of the Work Ability Index questionnaire", Occup Med (Lond), 52, 177-181. https://doi.org/10.1093/occmed/52.4.177.

34. Tuomi K., Ilmarinen J., Jahkola A. et al. (1998), Work ability Index, $2^{\text {nd }}$ edition. Helsinki, Finnish Institute of Occupational Health.

35. Camerino D., van der Heijden B., Estryn-Behar M., Kiss P. et al. (2003), "Work ability in the nursing profession", In: Hasselhorn H.-M., Tackenberg P., Müller B.H., eds. Working conditions and intent to leave the profession among nursing staff in Europe. Working Life Research Report 7. Stockholm: National Institute for Working Life, 88-93.

36. Kiss P., De Meester M., Kruse A., Chavée B. and Braeckman L. (2013), "Comparison between the first and second versions of the Copenhagen Psychosocial Questionnaire: psychosocial risk factors for a high need for recovery after work", Int Arch Occup Environ Health, 86, 17-24. https://doi.org/10.1007/s00420-012-0741-0.

37. Berthelsen H., Hakanen J., Kristensen T. S. et al. (2016), "A Gualitative Study on the Content Validity of the Social Capital Scales in the Copenhagen Psychosocial Questionnaire (COPSOQ II)", Scand J. Work Organ Psychol, 1 (1), 5, 1-13. https://doi.org/10.16993/ sjwop.5.

38. van Veldhoven M. and Broersen S. (2003), "Measurement quality and validity of the "need for recovery scale", Occup Environ Med, 60 (Suppl 1), i3-i9. https://doi.org/10.1136/oem.60.suppl_1.i3.

39. de Croon E. M., Sluiter J. K. and Frings-Dresen M. H. W. (2006), "Psychometric properties of the need for recovery after work scale: test-retest reliability and sensitivity to detect change", J. Occup Environ Med, 63, 202-206. https://doi.org/10.1136/oem.2004.018275.

40. van Amelsfoort L. G. P. M., Kant I. J., Bültmann U. and Swaen G. M. H. (2003), «Need for recovery after work and the subsequent risk of cardiovascular disease in a working population", J. Occup Environ Med, 60, i83-i87. https://doi.org/10.1136/oem.60.suppl_1.i83. 
ISSN 2223-6775, Ukrainian Journal of Occupational Health, 2019, 15 (4), 299-306

41. Jansen N. W. H., Kant I. J., van Amelsvoort L. G. P. M. et al. (2003), "Need for recovery from work: evaluating short-term effects of working hours, patterns and schedules", Ergonomics, 46, 664-680. https://doi.org/ 10.1080/0014013031000085662.

42. Broersen J. P. J., Fortuin R. J., Dijkstra M. et al. (2004), Monitor arboconvenanten: kengetallen en grenswaarden [in Dutch: Monitor occupational health and safety: key figures and limits], Tijdschrift voor Bedrijfs- en Verzekeringsgeneeskunde, 12, 100-104. https://doi.org/10.1007/BF03073999.

43. World Health Organization (WHO). (1993), Aging and working capacity: report of a WHO study group WHO technical report series 835. Geneva, World Health Organization.

44. IBM SPSS Statistics for Windows [computer program]. (2013), Version 22.0. Armonk, NY: IBM Corp.
45. Boschman J. S., van der Molen H. F., FringsDresen M. H. W. and Sluiter J. K. (2014), "The impact of common mental disorders on work ability in mentally and physically demanding construction work", Int Arch Occup Environ Health, 87, 51-59. https://doi.org/ 10.1007/s00420-012-0837-6.

46. van Holland B. J., Soer R., de Boer M. R. et al. (2015), "Workers' health surveillance in the meat processing industry: work and health indicators associated with work ability", J. Occup Rehabil, 25, 618626. https://doi.org/10.1007/s10926-015-9569-2.

47. Kiss P. and De Meester M. (2009), "Impact of psychosocial work environment factors measured by the COPSOG on the need for recovery after work in ageing workers. Preliminary results», In: Kumashiro M, ed. Promotion of work ability towards a productive aging. London, Taylor \& Francis, 239-245.

\section{Кісс Ф., 2, Ае Меестер М.1,2, Крістенсен Т. С. ${ }^{3}$, КАейс Е.2 , Брекман $\Lambda^{2}$ ЗВ'ЯЗОК МІХК НИЗЫКОЮ ПРАШЁААТНІСТЮ В ТРУАОВИХ КОАЕКТИВАХ ТА СОЩААЬНИМИ ВІАНОСИНАМИ - ПЕРЕХРЕСНИЙ АНААВ TPOMAACbKOTO CEKTOPA}

'Служба забезпечення професійного здоров'я, Бельгія

Аепартамент громадського здоров'я та первинної медичної

эКонсультативна робоча група, $\Delta$ жімележ, $\Delta$ анія

Мета дослідження - вивчити зв'язок між поширенням низької працездатності в трудових колективах і соціальними відносинами серед населення державного сектора.

Матеріали та методи дослідження. 836 представників визначених робочих колективів (середній показник відповідей на робочий колектив: 84,8 \%) з 7 організацій державного сектора взяли участь у перехресному анкетному дослідженні. Зв'язок між низькою працездатністю (індекс працездатності < 37), фізичним навантаженням, потребою у відновленні і соціальними відносинами вивчали на рівні робочих колективів з використанням двовимірних кореляцій і множинного лінійного регресійного аналізу.

Результати. Значна кореляція була встановлена між працездатністю, соціальними відносинами (r: -0,311) і високою потребою у відновленні (r: 0,501). Багатоваріантний аналіз показав, що потреба у відновленні (стандартний показник $\beta$ 0,521) і соціальні відносини на робочих місцях (стандартний показник $\beta$-0,321) значною мірою пов'язані з працездатністю в робочих колективах.

Висновки. Результати дослідження показують важливу роль необхідності відновлення та підтримки соціальних відносин у робочих колективах державного сектора. Необхідно враховувати фактори, які впливають на зменшення потреби у відновленні й на поліпшення соціальних відносин на робочому місці при розгляді підвищення працездатності.

Ключові слова: працездатність, необхідність відновлення, соціальні відносини на робочому місці, фізичне робоче навантаження, громадський сектор

Кисс Ф.1,2 , Ае Меестер М.1,2, Кристенсен Т. С.3, КАейс Э.2, Брекман А.2 СВЯЗЬ МЕХКАУ НИВКОЙ РАБОТОСПОСОБНОСТЬЮ В ТРУАОВЫХ КОА ЕКТИВАХ

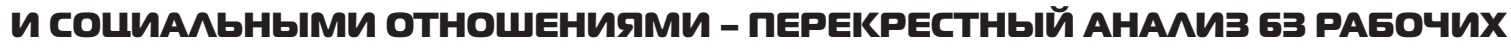
КОА ЕКТИВОВ ОБШЕСТВЕННОГО СЕКТОРА

'Служба обеспечения профессионального здоровья, Бельгия

${ }^{2} \Delta$ епартамент обшественного здоровья и первичной меАишинской помоши, Бельгия

эКонсультативная рабочая группа, Акиллележ, Аания

Цель исследования - изучить связь между распространением низкой трудоспособности в трудовых коллективах и социальными отношениями среди населения государственного сектора. 
Материалы и методы исследования. 836 испытуемых, представителей определенных рабочих коллективов (средний показатель ответов на рабочий коллектив: 84,8\%) в 7 организациях государственного сектора, приняли участие в перекрестном анкетном исследовании. Связь между низкой работоспособностью (индекс трудоспособности < 37), физической нагрузкой, потребностью в восстановлении и социальными отношениями изучали на уровне рабочих коллективов с использованием двумерных корреляций и множественного линейного регрессионного анализа.

Результаты. Значительная корреляция была установлена между трудоспособностью, социальными отношениями (r: -0,311) и высокой потребностью в восстановлении (r: 0,501). Многовариантный анализ показал, что потребность в восстановлении (стандартный показатель $\beta$ 0,521) и социальные отношения на рабочих местах (стандартный показатель $\beta-0,321)$ в значительной степени связаны с работоспособностью в рабочих коллективах.

Выводы. Результаты исследования показывают важную роль необходимости восстановления и поддержки социальных отношений в рабочих коллективах государственного сектора. Необходимо учитывать факторы, которые влияют на уменьшении потребности в восстановлении и на улучшение социальных отношений на рабочем месте при рассмотрении повышения трудоспособности.

Ключевые слова: работоспособность, необходимость восстановления, социальные отношения на рабочем месте, физическая рабочая нагрузка, общественный сектор

\section{Contributions of the authors:}

Kiss P. (ORCID ID 0000-0002-8812-9532) - conceived and designed the study, collected all data, analyzed and interpreted the data and drafted the manuscript;

De Meester M. (ORCID ID 0000-0001-9286-4399) - conceived and designed the study, collected all data, analyzed and interpreted the data and drafted the manuscript;

Kristensen T. S. (ORCID ID 0000-0003-2646-4818) - contributed in analysis and interpretation of data, critically revised the manuscript and provided feedback;

Clays E. (ORCID ID 0000-0002-1092-945X) - contributed in analysis and interpretation of data, critically revised the manuscript and provided feedback;

Braeckman L. (ORCID ID 0000-0002-6016-8134) - contributed in analysis and interpretation of data, critically revised the manuscript and provided feedback.

Fundings: No funding was received for this study.

Надійшла: 12 вересня 2019 р.

Прийнята до друку: 21 жовтня 2019 р.

Контактна особа: Кісс Ф., Служба забезпечення професійного здоров'я. Бельгія.

Тел.: + 32926581 50, факс: + 32923561 25. Електронна пошта: philippe.kiss@securex.be 